\title{
XENILLUS CLYPEATOR ROBINEAU-DESVOIDY AND ITS IDENTITY
}

\author{
By Arthur Paul Jacot
}

Shantung Christian University, Tsinan, China.

In 1839 André Jean Baptiste Robineau-Desvoidy described a new genus and species of beetle under the above name, which he secured on the twelfth of July on agarics of an old cherry tree at Saint-Sauveur, Yonne (about 100 miles south of Paris), France. General Dejean, to whom the unique specimen was presented, considered it an acarid and Lucas and Démary were appointed to restudy and report on it. They considered it as related to the Oribatids or Uropodids. It was then submitted through $\mathrm{Mr}$. Audouin to Antoine Louis Dugès who had made a few studies on Acarians, and who referred it to Oribates castanæ Hermann 1804 (type locality Strasbourg). Little did Dugès realize, nor did anyone of that time, the fact that any mesophytic locality can boast of 60-80 species. A comparison of Hermann's description of $O$. castanæ with that of $X$. clypeator brings out this point, the former being nearly spherical not ovoid, shining not granular, cephaloprothorax short, not rather long.

A carefull perusal of Robineau-Desvoidy's description reveals two important points (1) he mistakes the anterior pair of legs for antennæ (giving them 5 joints) thus giving his animal three pairs of legs, instead of four, (2) he mistakes the pseudostigmata for eyes.

The description of Lucas and Démary who were, especially Lucas, much more competant students, is far more detailed than that of the finder and is the basis for the present study. They describe the "antennæ" as broken off so short as to leave but a small, cylindric pedicel. Their description includes three outstanding clues to the generic relations of this animal: (1) no plate or wing-like outgrowths to the "carapace" (notogaster) are mentioned in 
a detailed description and as this is a conspicuous feature, one may consider them as lacking; (2) the armature of the cephaloprothorax is described chiefly on pages $466-467$. Most of page 467 is taken up with the description of a structure which Nicolet called a tectum or head-roof. (3) The notogaster (last line of page 468) is described as oval, vaulted (like the carapace of a turtle) with rugose, shagreened surface (Robineau-Desvoidy called it granular).

Fortunately there is but one group of apterogasterine Oribatids to which this description applies, namely, that called Cepheus by Nicolet (not Koch). A more detailed comparison of the description of Lucas and Demary, with the species figured by Nicolet and by Michæl under the names Cepheus vulgaris, $C$. tegeocranus and $C$. latus will make this identity the more certain.

In describing the cephaloprothorax these authors first describe (p. 466) the structure of the portion below the tectum. Of this they say: "Four main pieces form this head, three latero-superior and one inferior. Two of the laterosuperior pieces are thin, transversely flattened, and articulate posteriorly with the first piece which forms the thorax or rather the cephalothorax; they are directed forward and approximate each other so as to circumscribe a triangular space which encloses the third medio-superior piece. [These two latero-superior pieces are thus the genæ of Michæl]. This latter articulates behind with the median and anterior part of that kind of shield which covers over the body [notogaster] [i. e. it is the rostrum and dorsovertex of Michæl]. Laterally it merges with the projecting blades or ears which we have already indicated [preceding paragraph, i. e. lamellæ]; as it proceeds anteriorly they gradually narrow or turn inward, and terminate at the anterior part of the two lateral plates [genæ], but without merging intimately with them, so that one distinguishes at their ends two little grooves separating three little tubercles called the upper lip. [This condition is clearly indicated in Michæl's 1883 volume, pl. 16, fig. 9: C. tegeocranus, where $a$ is the medio-lateral piece separated from the triangular lateral piece by a slender tectopedial ridge, also in Nicolet, pl. 7 (31), fig. 8c where the rostral bristle is shown on a 
tubercular projection of the tectopedium]. They receive in their spread an inferior, horizontal piece which springs from below the first segment of the thorax, bends at its anterior part and houses itself in the midst of the three others. This single piece, larger than each of the preceding, constitutes of itself, the labium."

"Above this head one finds a solid organ which surpasses it at the sides, and gives it [the head] the appearance of being retracted beneath its lower [proximal] part; it is composed of three pieces, two lateral and a median. The median piece is convex, closely fused with the two lateral pieces, near the posterior half of its lateral edges, and ends anteriorly, as already stated between the two pieces of the upper lip [genæ]. The two lateral pieces [lamellæ] are triangular; situated on a higher plane than the median piece, they seem to continue by their exterior edges the curve form by the sides of the carapace [notogaster] [see Michæl 1883, pl. 17, figs. 1 and 12 or Nicolet pl. 7 (31), fig. 9]. Their small end directed forward is pointed, projecting, but does not extend to the extremity of the head; their base articulates with the anterior and lateral part of the dorsal piece [i. e. notogaster]; their inner edges recurve and merge, first [on the inside] with the median piece [of the tectum], then [on the outside] with the lateral pieces of the upper lip [i. e. the proximal part of the genæ or acropleuron of Michæl], forming with them an obtuse more or less rounded angle. These two lateral pieces [lamellæ] include between them and the genæ, a deep groove which encloses, at its posterior part, a small, round black eye, without facets [pseudostigmata], and, a little below this thing, that little cylindrical body which we have noted as probably being the first article of the antennæ described by Robineau-Desvoidy [i. e. coxa of leg I]."

Thus the description corresponds accurately with these so called Cepheus and as he describes the apex of the lamellæ as pointed, it would seem to be $C$. vulgaris Nicolet (=N. tegecranus Hermann). The generic identity is further corroborated by the description of the legs which Michæl has figured on plate 17. Lucas and Démary say: "We have 
been struck by the largeness and length of the coxa [hanche] of the third [i. e. fourth] pair of legs ; this last dimension equals at least half that of the femur [cuisse] [fig. 10]. This is so much the more remarkable, as in the other pairs of legs the coxa is barely perceptible and the femur is slender [figs. 8 and 9]. The tibias do not diminish in size at the femoral end, but are more slender at the middle." This is particularly interesting and unusual. The remainder of the paragraph is inaccurate and irrelevant.

Finally, it is significant that without stretching the description to fit the species $X$. clypeator should be the commonest species of this genus occuring in central Europe. Although this species (like the elephant and the tea-pot) is not known to climb trees, is is not certain that the agarics were on standing trees, while it is reported by Michæl to burrow in moss and old wood.

Until, therefore, Xenillus clypeator can be proved to ressemble more some other species, point for point, than it does Cepheus tegeocranus of early authors, in structure and habits, it will have to be considered monotype of the genus Xenillus and synonym of $N$. tegeocranus Hermann 1804 or : Xenillus tegeocranus (Hermann). 

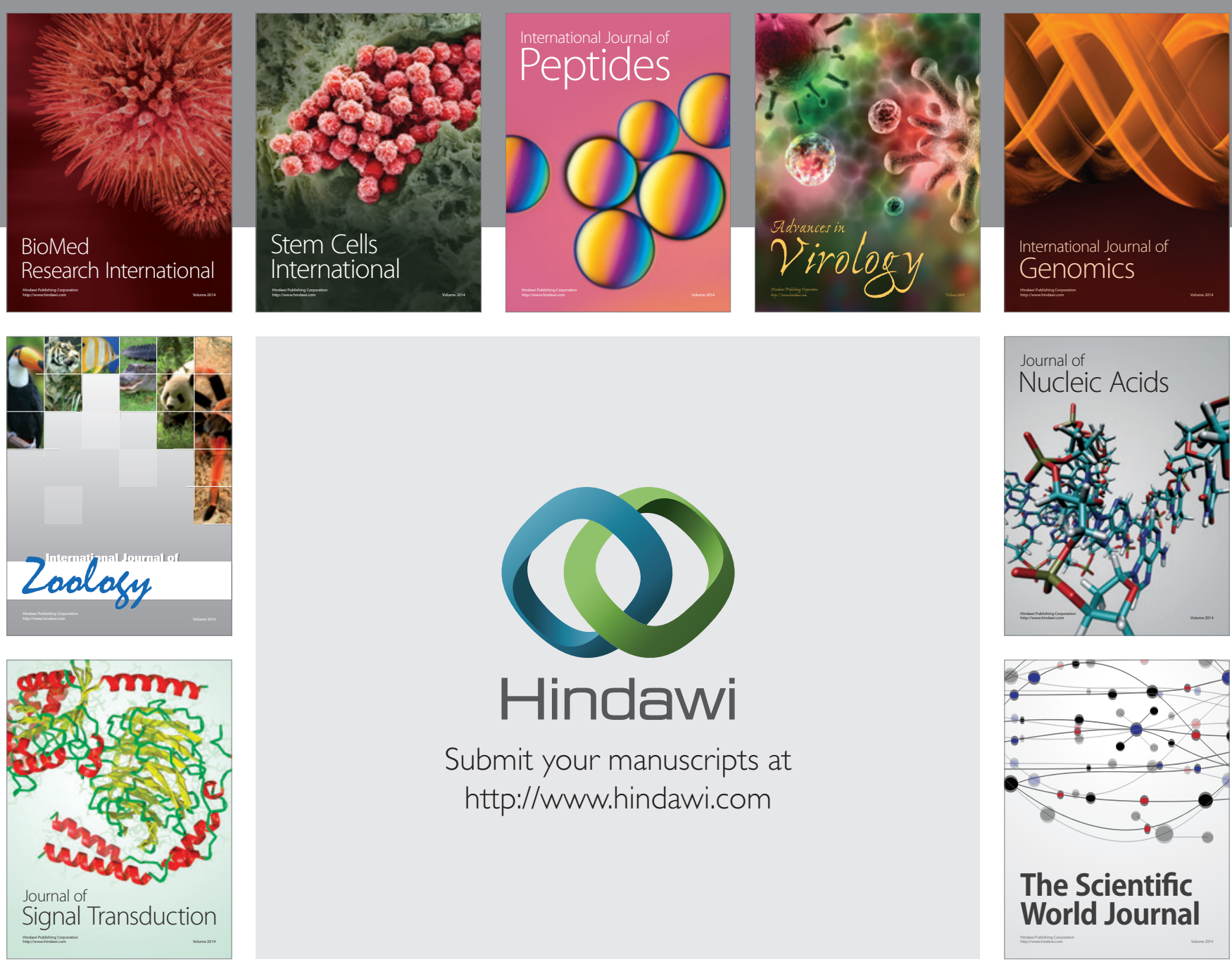

Submit your manuscripts at

http://www.hindawi.com
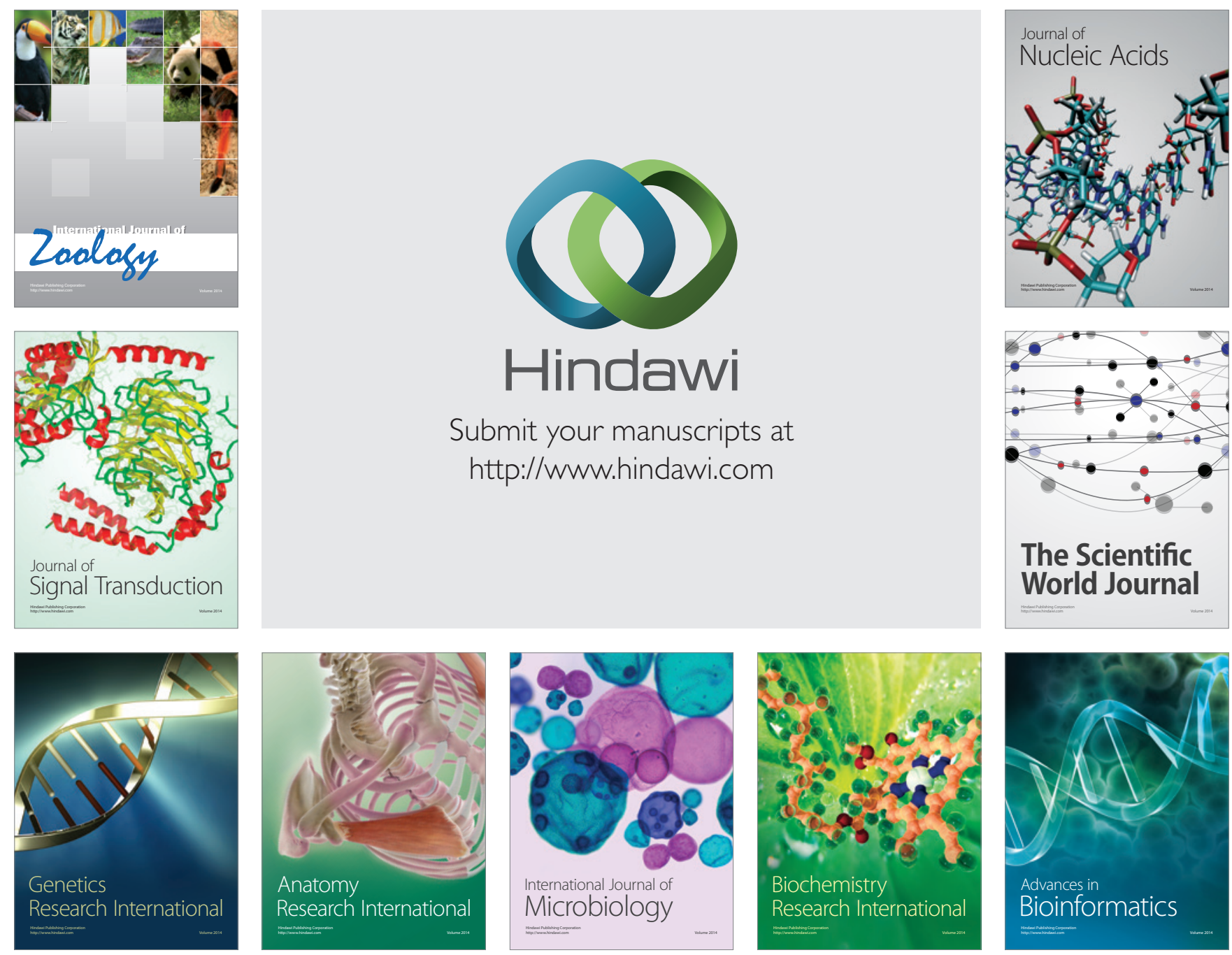

The Scientific World Journal
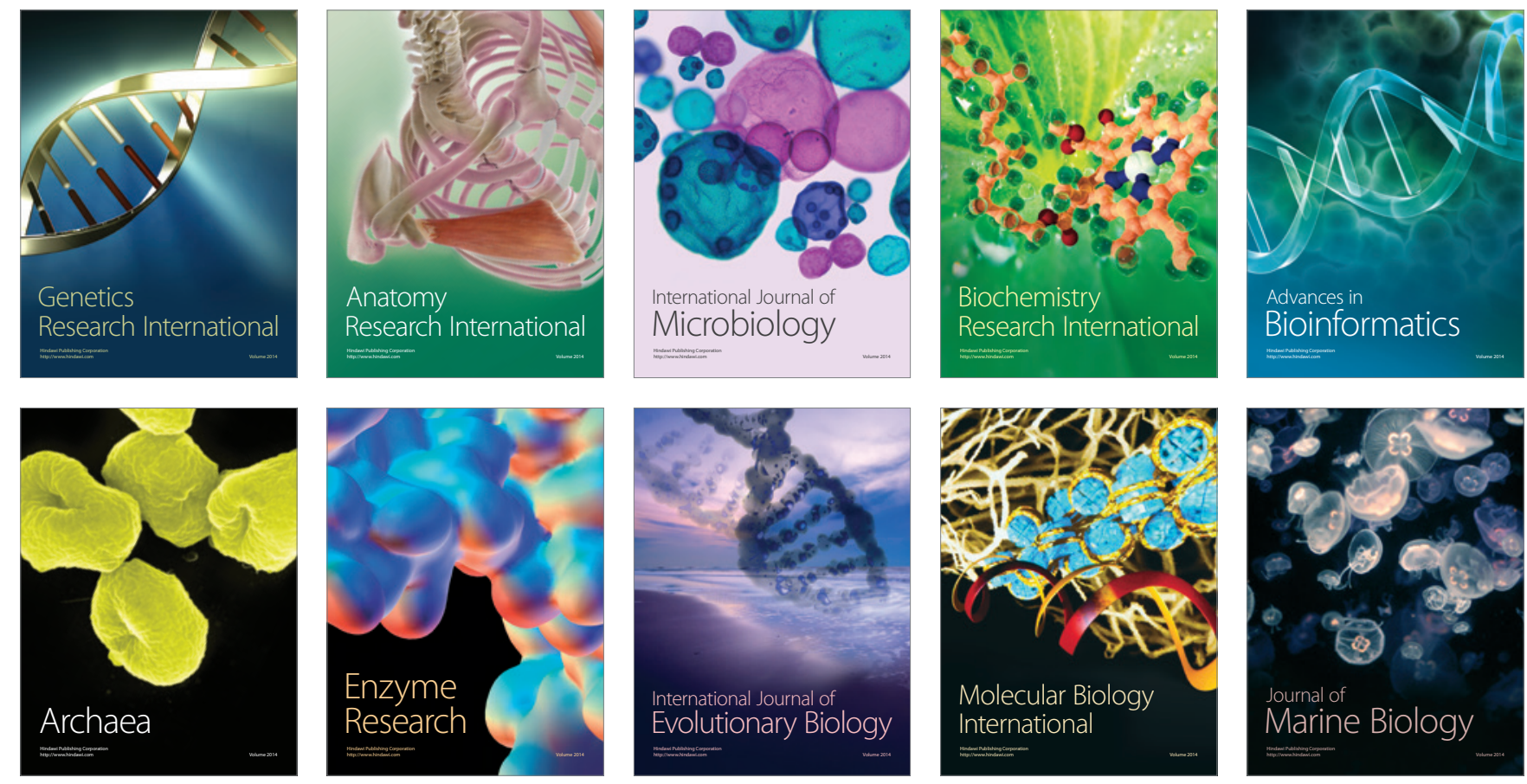